\title{
The effect of titanium dioxide nanoparticles on pulmonary surfactant function and ultrastructure
}

\author{
Carsten Schleh ${ }^{1,2}$, Christian Mühlfeld ${ }^{3}$, Karin Pulskamp ${ }^{4}$, Andreas Schmiedl ${ }^{5}$, \\ Matthias Nassimi 1,6, Hans D Lauenstein ${ }^{1,2}$, Armin Braun ${ }^{1}$, Norbert Krug ${ }^{1}$, \\ Veit J Erpenbeck ${ }^{1,2}$ and Jens M Hohlfeld ${ }^{* 1,2}$
}

\begin{abstract}
Address: ${ }^{1}$ Fraunhofer Institute of Toxicology and Experimental Medicine, Division of Immunology, Allergology and Airway Research, NikolaiFuchs-Str. 1, 30625 Hannover, Germany, ${ }^{2}$ Department of Respiratory Medicine, Hannover Medical School, Germany, ${ }^{3}$ Institute of Anatomy, Division of Histology, University of Bern, Switzerland, ${ }^{4}$ Forschungszentrum Karlsruhe, Institute of Toxicology and Genetics, Department of Molecular and Environmental Toxicology, Germany, ${ }^{5}$ Institute of Functional and Applied Anatomy, Hannover Medical School, Germany and ${ }^{6}$ Department of Pharmaceutics, Technical University Carolo-Wilhelmina at Braunschweig, Germany

Email: Carsten Schleh - carsten.schleh@item.fraunhofer.de; Christian Mühlfeld - christian.muehlfeld@ana.unibe.ch; Karin Pulskamp - karin.pulskamp@gmx.de; Andreas Schmiedl - schmiedl.andreas@mh-hannover.de;

Matthias Nassimi - matthias.nassimi@item.fraunhofer.de; Hans D Lauenstein - hans-dieter.lauenstein@item.fraunhofer.de;

Armin Braun - armin.braun@item.fraunhofer.de; Norbert Krug - norbert.krug@item.fraunhofer.de; Veit J Erpenbeck - veit.erpenbeck@merck.de; Jens M Hohlfeld* - jens.hohlfeld@item.fraunhofer.de

* Corresponding author
\end{abstract}

Published: 30 September 2009

Respiratory Research 2009, 10:90 doi:10.1186/1465-9921-10-90
Received: 17 April 2009

Accepted: 30 September 2009

This article is available from: http://respiratory-research.com/content//0/1/90

(C) 2009 Schleh et al; licensee BioMed Central Ltd.

This is an Open Access article distributed under the terms of the Creative Commons Attribution License (http://creativecommons.org/licenses/by/2.0), which permits unrestricted use, distribution, and reproduction in any medium, provided the original work is properly cited.

\begin{abstract}
Background: Pulmonary surfactant reduces surface tension and is present at the air-liquid interface in the alveoli where inhaled nanoparticles preferentially deposit. We investigated the effect of titanium dioxide $\left(\mathrm{TiO}_{2}\right)$ nanosized particles (NSP) and microsized particles (MSP) on biophysical surfactant function after direct particle contact and after surface area cycling in vitro. In addition, $\mathrm{TiO}_{2}$ effects on surfactant ultrastructure were visualized.
\end{abstract}

Methods: A natural porcine surfactant preparation was incubated with increasing concentrations $(50-500 \mu \mathrm{g} / \mathrm{ml})$ of $\mathrm{TiO}_{2}$ NSP or MSP, respectively. Biophysical surfactant function was measured in a pulsating bubble surfactometer before and after surface area cycling. Furthermore, surfactant ultrastructure was evaluated with a transmission electron microscope.

Results: $\mathrm{TiO}_{2}$ NSP, but not MSP, induced a surfactant dysfunction. For $\mathrm{TiO}_{2} \mathrm{NSP}$, adsorption surface tension $\left(\gamma_{\text {ads }}\right)$ increased in a dose-dependent manner from $28.2 \pm 2.3 \mathrm{mN} / \mathrm{m}$ to $33.2 \pm 2.3$ $\mathrm{mN} / \mathrm{m}(\mathrm{p}<0.0 \mathrm{I})$, and surface tension at minimum bubble size $\left(\gamma_{\mathrm{min}}\right)$ slightly increased from $4.8 \pm$ $0.5 \mathrm{mN} / \mathrm{m}$ up to $8.4 \pm 1.3 \mathrm{mN} / \mathrm{m}(\mathrm{p}<0.0 \mathrm{I})$ at high $\mathrm{TiO}_{2}$ NSP concentrations. Presence of NSP during surface area cycling caused large and significant increases in both $\gamma_{\text {ads }}(63.6 \pm 0.4 \mathrm{mN} / \mathrm{m})$ and $\gamma_{\min }(2 \mathrm{I} .1 \pm 0.4 \mathrm{mN} / \mathrm{m})$. Interestingly, $\mathrm{TiO}_{2} \mathrm{NSP}$ induced aberrations in the surfactant ultrastructure. Lamellar body like structures were deformed and decreased in size. In addition, unilamellar vesicles were formed. Particle aggregates were found between single lamellae.

Conclusion: $\mathrm{TiO}_{2}$ nanosized particles can alter the structure and function of pulmonary surfactant. Particle size and surface area respectively play a critical role for the biophysical surfactant response in the lung. 


\section{Background}

High amounts of ambient particulate matter (PM) exist in our atmosphere, and it is known that a high proportion of these particles are nanosized particles (NSP) with a diameter of $\leq 100 \mathrm{~nm}$. NSP can be found in the air as a result of combustion processes such as automobile engines and fires. In addition, the rapidly developing field of nanotechnology is becoming a potential source for human exposure to NSP. Titanium dioxide $\left(\mathrm{TiO}_{2}\right)$ NSP e.g. are widely produced for industrial processes since several years [1].

Importantly, PM exposure is linked with the occurrence of cardio-respiratory disease as well as mortality $[2,3]$. Epidemiological and experimental data suggest a relationship between PM and e.g. asthma [4], chronic obstructive pulmonary disease [5], and cystic fibrosis [6,7]. Unfortunately, the exact mechanism by which PM induces or aggravates airway disease is still unknown.

Dependent on their size, particles preferentially deposit in different compartments of the lung. Importantly, most of the nanosized particles have a high alveolar deposition rate [8]. In the alveoli, these particles come into contact with the pulmonary surfactant layer that covers the entire alveolar region. Surfactant decreases the surface tension at the air-liquid interface and thereby prevents alveolar collapse. Surface activity is mainly accomplished by surfactant phospholipids and the specific surfactant proteins (SP)-B, and -C. Morphologically, surfactant exists in different subfractions. The surface active fraction consists of lamellar bodies and tubular myelin whereas the less surface active fraction is comprised of unilamellar vesicles. By ultracentrifugation, lamellar bodies and tubular myelin can be pelleted and are thereby called large aggregates (LA). In contrast, unilamellar vesicles remain in the supernatant and are defined as small aggregates (SA). Conversion of LA into SA occurs during respiration [9].

It has been demonstrated that particles of anthropogenic origin are able to directly interact with pulmonary surfactant components [10-13]. Further, it has been shown that nanosized particles can disturb surfactant function $[14,15]$. However, a systematic comparison of nanosized and microsized particles (MSP) of different composition has not been made. Moreover, it is unclear whether particle-surfactant interactions during dynamic conditions of surface area cycling aggravate the biophysical surfactant dysfunction. Therefore, we investigated the effect of increasing concentrations of $\mathrm{TiO}_{2} \mathrm{NSP}$ and $\mathrm{TiO}_{2} \mathrm{MSP}$, as model particles, on pulmonary surfactant function by means of a pulsating bubble surfactometer both under native conditions and following surface area cycling. For comparison reasons, the effect on surfactant function was investigated for nanosized and microsized polystyrene particles as well as for quartz particles. Furthermore, we studied the effect of nanosized $\mathrm{TiO}_{2}$ particles on surfactant ultrastructure by transmission electron microscope (TEM). In order to elaborate on the in-vivo relevance, rats were exposed to $\mathrm{TiO}_{2}$ NSP versus $\mathrm{TiO}_{2}$ MSP, lungs were fixed and lung tissue blocks were prepared for electron microscopy. The ultrastructure and distribution of the different subtypes of intra-alveolar surfactant was observed.

\section{Methods \\ Particles}

Nanosized and microsized titanium dioxide particles (Alfa Aesar, Karlsruhe, Germany; product numbers: 44689 \& 42681) were used in this study. For comparison, polystyrene particles (Micromod, Rostock-Warnemuende, Germany), Sikron SF 800 quartz particles (Quarzwerke, Frechen, Germany) as well as citrate coated nanosized gold particles (Plano, Wetzlar Germany: product number: EM.GC5) were studied [for details see additional file 1]. Particle stock solutions were prepared in sterilized bidistilled water at a concentration of $25 \mathrm{mg} / \mathrm{ml}$ or $50 \mathrm{mg} / \mathrm{ml}$. Particles were sonicated prior to each experiment.

\section{Acute Effects on Biophysical Surfactant Function}

A natural porcine surfactant preparation (Curosurf ${ }^{\circledast}$, Asche Chiesi, Hamburg, Germany) was used as a standard and was adjusted to $1.5 \mathrm{mg} / \mathrm{ml}$ phospholipids in Ringer's solution. Particles at increasing concentrations were added $(50 \mu \mathrm{g} / \mathrm{ml} \mathrm{-} 500 \mu \mathrm{g} / \mathrm{ml})$ and biophysical surfactant function was assessed with a pulsating bubble surfactometer (PBS) (Electronetics, Buffalo, NY, USA) as described below.

\section{Surface Area Cycling}

Surface area cycling is a standardized method to simulate the in vivo conversion of surface active surfactant subtypes (lamellar bodies, tubular myelin) to inferior surfactant subtypes (unilamellar vesicles) in vitro [16-20]. We measured the biophysical surfactant function following surface area cycling in the presence or absence of particles in order to assess the effect of particles during the conversion process. Curosurf ${ }^{\circledR}$ was adjusted to $1.5 \mathrm{mg} / \mathrm{ml}$ phospholipids in ringer solution with or without particles in increasing concentrations $(50 \mu \mathrm{g} / \mathrm{ml}-500 \mu \mathrm{g} / \mathrm{ml})$. Aliquots were placed in $12 \times 75 \mathrm{~mm}$ capped plastic tubes (Falcon 2058) and rotated end over end for 8 hours at $0.43 \mathrm{~Hz}$ and $37^{\circ} \mathrm{C}$ in the dark. Thereby, surface area changed from $1.1 \mathrm{~cm}^{2}$ to $9 \mathrm{~cm}^{2}$ twice per cycle. After surface area cycling biophysical surfactant function was measured in a pulsating bubble surfactometer as described below.

\section{Surface Activity Evaluated with the Pulsating Bubble Surfactometer}

Surface activity of pulmonary surfactant was measured with a PBS. Forty $\mu$ l of the surfactant mixture were filled into the sample chamber. The surface tension used for sta- 
tistical analysis of this study was the value at minimum bubble size $\left(\gamma_{\min }\right)$ registered after 330 seconds of pulsation at a rate of 20 cycles $/ \mathrm{min}$ and a temperature of $37^{\circ} \mathrm{C}$. In addition, adsorption surface tension $\left(\gamma_{\mathrm{ads}}\right)$ was evaluated by determining surface tension $10 \mathrm{~s}$ after formation of a bubble under static bubble conditions. All data were digitalized and recorded by computer. All assays were performed in duplicate and the mean value was reported. The PBS was calibrated and checked with reference substances for proper operation before starting the measurements on each day.

\section{Transmission Electron Microscope}

Surfactant was fixed in Eppendorf tubes with 1.5\% glutaraldehyde and $1.5 \%$ paraformaldehyde in $0.15 \mathrm{M}$ Hepes buffer. The samples were stored in the fixative for 1 hour at room temperature and at least 24 hours at $4{ }^{\circ} \mathrm{C}$. Afterwards, samples were centrifuged at $10,000 \mathrm{~g}$ to obtain a surfactant pellet. After several washings in buffer, the samples were subsequently postfixed in osmium tetroxide and half-saturated aqueous uranyl acetate, dehydrated in an ascending acetone series and embedded in Epon at $60^{\circ} \mathrm{C}$. The Eppendorf cups were removed and ultrathin $50 \mathrm{~nm}$ sections were cut using an ultramicrotome. The sections were analyzed with a Philips CM12 transmission electron microscope (FEI Co. Philips Electron Optics, Zürich, Switzerland).

\section{Exposure of rats to particles and assessment of surfactant ultrastructure}

Female Wistar rats (162 - $200 \mathrm{~g}$ ) were randomly exposed once for 6 hours to either $\mathrm{TiO}_{2}$ NSP (P25; Evonik Degussa, Essen, Germany), $\mathrm{TiO}_{2} \mathrm{MSP}$ (Bayertitan $\mathrm{T}$, Bayer, Leverkusen, Germany), or clean air, respectively ( $n=5$ per group). The exposure atmosphere was adjusted to either $10 \mathrm{mg} \mathrm{TiO}{ }_{2} \mathrm{MSP} / \mathrm{m}^{3}$ or $25 \mathrm{mg} \mathrm{TiO} 2 \mathrm{NSP} / \mathrm{Na}_{2} \mathrm{HPO}_{4} / \mathrm{m}^{3}$ $\left(60 \% \mathrm{Na}_{2} \mathrm{HPO}_{4} ; 40 \% \mathrm{TiO}_{2} \mathrm{NSP}\right)$. Since the $\mathrm{TiO}_{2} \mathrm{MSP}$ and $\mathrm{TiO}_{2} \mathrm{NSP} / \mathrm{Na}_{2} \mathrm{HPO}_{4}$ droplets in the atmosphere were approximately of the same size, a similar alveolar deposition rate of $60 \mu \mathrm{g} \mathrm{TiO}_{2}$ particles per animal was accomplished [21]. Rats were sacrificed by pentobarbital overdose at the end of the exposure and the lungs were perfusion-fixated as described before [22]. Surfactant ultrastructure was assessed on ultrathin sections by electron microscopy and surfactant subtype conversion was studied semiquantitatively.

\section{Statistical Analysis}

Values are given as means \pm SEM. Statistical analysis was performed using GraphPad Prism ${ }^{\circledast}$, Version 4.03. The oneway ANOVA was used for statistical analysis of the data. A Bonferroni correction was used throughout. P values < 0.05 were considered to be significant.

\section{Results \\ Direct Effect of Particles on Pulmonary Surfactant Function}

To assess the direct effect of particles on surfactant function, surface tension was measured after addition of particles. Pure surfactant showed an adsorption surface tension of $\sim 28 \mathrm{mN} / \mathrm{m}$ and addition of $\mathrm{TiO}_{2}$ NSP in concentrations up to $200 \mu \mathrm{g} / \mathrm{ml}$ did not affect this active surface tension (Figure 1A). However, further increase of the particle dose up to $500 \mu \mathrm{g} / \mathrm{ml}$ led to a significant increase in adsorption surface tension to $33.2 \pm 2.3 \mathrm{mN} / \mathrm{m}$. In contrast, surface tension was unaffected by treatment with the same mass concentrations of $\mathrm{TiO}_{2} \mathrm{MSP}$ (Figure $1 \mathrm{~B}$ ). $\mathrm{TiO}_{2}$ NSP slightly increased $\gamma_{\min }$ from $\leq 5 \mathrm{mN} / \mathrm{m}$, which denotes active surfactant, up to $8.4 \pm 1.3 \mathrm{mN} / \mathrm{m}$ at $500 \mu \mathrm{g} / \mathrm{ml}$ (Figure $1 \mathrm{C}$ ). Again, $\mathrm{TiO}_{2} \mathrm{MSP}$ showed no effect on surface tension in this concentration range (Figure 1D). However, at very high particle concentrations of $\mathrm{TiO}_{2} \mathrm{MSP}(\sim 10 \mathrm{mg} / \mathrm{ml})$ that deliver a similar surface area compared to $\mathrm{TiO}_{2} \mathrm{NSP}$ $\gamma_{\text {min }}$ increased to $15.9 \pm 1.3 \mathrm{mN} / \mathrm{m}(\mathrm{n}=6, \mathrm{p}<0.01)$.

As for the $\mathrm{TiO}_{2}$ particles similar results were observed for the other particles. Whereas polystyrene NSP significantly increased adsorption surface tension for $500 \mu \mathrm{g} / \mathrm{ml}$, polystyrene and quartz MSP did not influence the surface tension up to a concentration of $500 \mu \mathrm{g} / \mathrm{ml}$ (Table 1). In addition, nanosized polystyrene particles increased surface tension at minimum bubble size significantly at 500 $\mu \mathrm{g} / \mathrm{ml}$ up to $6.8 \pm 1.2 \mathrm{mN} / \mathrm{m}$, whereas microsized particles did not influence surfactant function in this concentration range (Table 1). Again, MSP (Quartz) at a very high concentration $(\sim 10 \mathrm{mg} / \mathrm{ml})$ that deliver a similar surface area compared to $\mathrm{TiO}_{2}$ NSP increased $\gamma_{\min }$ to $15.5 \pm 1.8 \mathrm{mN} / \mathrm{m}$ $(\mathrm{n}=5, \mathrm{p}<0.05)$.

Furthermore, we tested commercially available gold NSP with citrate coating $(5 \mathrm{~nm})$ in single experiments. At 200 $\mu \mathrm{g} / \mathrm{ml}$ and $500 \mu \mathrm{g} / \mathrm{ml}$, gold NSP increased $\gamma_{\min }$ to $7.7 \pm 2.8$ and $13.2 \pm 5.3$, respectively $(n=4)$.

\section{Effects of Particles Following Surface Area Cycling}

Surface area cycling alone led to an increase in adsorption surface tension from $\sim 28$ to $\sim 45 \mathrm{mN} / \mathrm{m}$ (Figure $2 \mathrm{~A}$ and 2B). The presence of $\mathrm{TiO}_{2}$ NSP in concentrations of 200 $\mu \mathrm{g} / \mathrm{ml}$ and $500 \mu \mathrm{g} / \mathrm{ml}$ during the cycling process led to a further increase of adsorption surface tension to $53.3 \pm$ $1.3 \mathrm{mN} / \mathrm{m}$ and $63.6 \pm 0.4 \mathrm{mN} / \mathrm{m}$, respectively (Figure $2 \mathrm{~A}$ ). $\mathrm{TiO}_{2}$ MSP concentrations up to $500 \mu \mathrm{g} / \mathrm{ml}$ did not affect adsorption surface tension (Figure $2 \mathrm{~B}$ ). The influence of $\mathrm{TiO}_{2}$ NSP on surface tension at minimum bubble size was pronounced (Figure $2 \mathrm{C}$ ). $\mathrm{TiO}_{2} \mathrm{NSP}$ at $100 \mu \mathrm{g} / \mathrm{ml}$ led to a significant increase in surface tension from $1.1 \pm 0.1 \mathrm{mN} /$ $\mathrm{m}$ up to $8.4 \pm 3.1 \mathrm{mN} / \mathrm{m}$. Further increase of particle dose induced a strong surfactant dysfunction with $\gamma_{\min }$ of 18.0 $\pm 1.6 \mathrm{mN} / \mathrm{m}$ and $21.1 \pm 0.4 \mathrm{mN} / \mathrm{m}$ after incubation with 

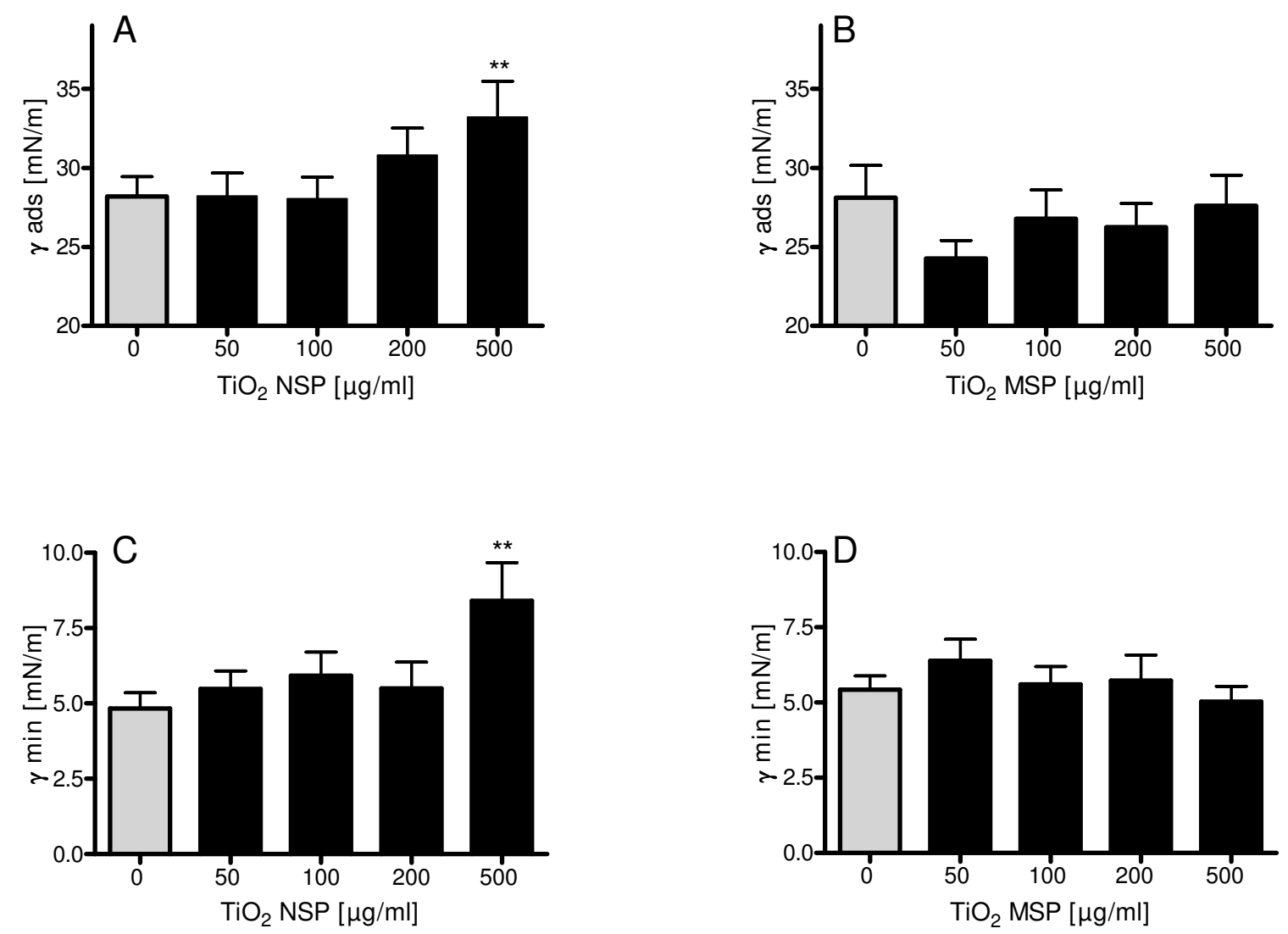

Figure I

Surface activity evaluated with the pulsating bubble surfactometer. A) Adsorption surface tension $\left(\gamma_{\text {ads }}\right)$ after incubation with $\mathrm{TiO}_{2}$ nanosized particles (NSP) at a static bubble condition. B) Influence of $\mathrm{TiO}_{2}$ microsized particles (MSP) on $\gamma_{\text {ads }}$ C) Influence of $\mathrm{TiO}_{2}$ NSP on surface tension at minimal bubble size $\left(\gamma_{\min }\right)$ during pulsation D) $\gamma_{\min }$ after incubation with TiO $\mathrm{MSP}$. Values are given as means of at least 4 experiments \pm SEM. ** indicates $\mathrm{p}$ values $<0.0 \mathrm{I}$ compared with the control at $0 \mu g / \mathrm{ml}$ particle concentration.

$200 \mu \mathrm{g} / \mathrm{ml}$ and $500 \mu \mathrm{g} / \mathrm{ml} \mathrm{TiO}_{2} \mathrm{NSP}$, respectively. $\mathrm{TiO}_{2}$ MSP led to a slight but non-significant increase in $\gamma_{\min }$ (Figure 2D).

Polystyrene NSP led to a slight increase in adsorption surface tension from $45.7 \pm 1.0 \mathrm{mN} / \mathrm{ml}$ up to $51.4 \pm 0.9 \mathrm{mN} /$ ml which was only significant at a concentration of 500 $\mu \mathrm{g} / \mathrm{ml}$ polystyrene NSP (Table 1 ). All other MSP did not influence adsorption surface tension (Table 1). Surface tension at minimum bubble size was also unaffected by polystyrene MSP and quartz MSP (Table 1), while polystyrene NSP induced a strong surfactant dysfunction at minimum bubble size. Incubation with $500 \mu \mathrm{g} / \mathrm{ml}$ polystyrene NSP during the cycling process led to a surface tension of $17.5 \pm 1.4 \mathrm{mN} / \mathrm{m}$ (Table 1 ).

\section{Influence of Nanosized $\mathrm{TiO}_{2}$ Particles on Surfactant} Ultrastructure

Natural porcine surfactant used in this study consisted mostly of lamellar body-like forms. Unilamellar vesicles were hardly present (Figure $3 \mathrm{~A}$ and $3 \mathrm{~B}$ ). After addition of $100 \mu \mathrm{g} / \mathrm{ml} \mathrm{TiO}_{2} \mathrm{NSP}$, lamellar body-like forms were decreased in size and deformed (Figure 3C). In addition, an increase in the amount of unilamellar vesicles appeared (Figure 3C). Interestingly, small $\mathrm{TiO}_{2} \mathrm{NSP}$ aggregates accumulated between lamellae of the lamellar bodylike forms (Figure 3D). Rotation of the pure surfactant in the absence of particles readily led to a conversion of lamellar body-like forms to unilamellar vesicles (Figure $3 \mathrm{E})$. Rotation in the presence of $\mathrm{TiO}_{2} \mathrm{NSP}$ did not further change subtype conversion (Figure 3F). However, large 
Table I: Surface activity evaluated with the pulsating bubble surfactometer.

\begin{tabular}{|c|c|c|c|}
\hline & Polystyrene NSP & Polystyrene MSP & Quartz MSP \\
\hline \multicolumn{4}{|c|}{ Direct effects $-\gamma_{\text {ads }}[\mathrm{mN} / \mathrm{m}]$} \\
\hline $0 \mu \mathrm{g} / \mathrm{ml}$ & $29.2 \pm 1.5$ & $28.9 \pm 2.7$ & $25.9 \pm 1.5$ \\
\hline $50 \mu \mathrm{g} / \mathrm{ml}$ & $28.3 \pm 1.4$ & $28.3 \pm 2.2$ & $25.0 \pm 1.6$ \\
\hline $100 \mu \mathrm{g} / \mathrm{ml}$ & $30.8 \pm 2.2$ & $28.6 \pm 2.3$ & $25.0 \pm 2.0$ \\
\hline $200 \mu \mathrm{g} / \mathrm{ml}$ & $32.4 \pm 2.1$ & $30.1 \pm 3.0$ & $26.3 \pm 2.9$ \\
\hline $500 \mu \mathrm{g} / \mathrm{ml}$ & $34.1 \pm 2.2^{* *}$ & $28.3 \pm 2.3$ & $25.2 \pm 1.5$ \\
\hline \multicolumn{4}{|c|}{ Direct effects $-\gamma_{\min }[\mathrm{mN} / \mathrm{m}]$} \\
\hline $0 \mu \mathrm{g} / \mathrm{ml}$ & $4.0 \pm 0.9$ & $2.4 \pm 1.2$ & $4.9 \pm 0.5$ \\
\hline $50 \mu \mathrm{g} / \mathrm{ml}$ & $5.1 \pm 0.9$ & $2.2 \pm 0.9$ & $4.1 \pm 0.9$ \\
\hline $100 \mu \mathrm{g} / \mathrm{ml}$ & $4.0 \pm 1.0$ & $2.8 \pm 1.8$ & $4.6 \pm 0.8$ \\
\hline $200 \mu \mathrm{g} / \mathrm{ml}$ & $4.7 \pm 1.1$ & $3.1 \pm 1.3$ & $4.1 \pm 0.9$ \\
\hline $500 \mu \mathrm{g} / \mathrm{ml}$ & $6.8 \pm 1.2^{* *}$ & $3.0 \pm 1.5$ & $5.0 \pm 0.8$ \\
\hline \multicolumn{4}{|c|}{ Surface area cycling $-\gamma_{\text {ads }}[\mathrm{mN} / \mathrm{m}]$} \\
\hline Control & $27.1 \pm 1.5$ & $27.4 \pm 2.7$ & $28.1 \pm 0.8$ \\
\hline $0 \mu \mathrm{g} / \mathrm{ml}$ & $45.7 \pm 1.0$ & $46.4 \pm 1.3$ & $43.7 \pm 0.8$ \\
\hline $50 \mu \mathrm{g} / \mathrm{ml}$ & $42.4 \pm 2.2$ & $43.7 \pm 2.2$ & $47.1 \pm 0.9$ \\
\hline $100 \mu \mathrm{g} / \mathrm{ml}$ & $47.1 \pm 1.3$ & $43.1 \pm 0.8$ & $45.8 \pm 2.8$ \\
\hline $200 \mu \mathrm{g} / \mathrm{ml}$ & $44.6 \pm 2.1$ & $45.3 \pm 2.3$ & $45.4 \pm 3.1$ \\
\hline $500 \mu \mathrm{g} / \mathrm{ml}$ & $51.4 \pm 0.9^{*}$ & $42.7 \pm 1.7$ & $48.4 \pm 1.5$ \\
\hline \multicolumn{4}{|c|}{ Surface area cycling $-\gamma_{\min }[\mathrm{mN} / \mathrm{m}]$} \\
\hline Control & $1.1 \pm 0.2$ & $1.1 \pm 0.2$ & $1.2 \pm 0.4$ \\
\hline $0 \mu \mathrm{g} / \mathbf{m l}$ & $\mathrm{I} .2 \pm 0.2$ & $1.1 \pm 0.2$ & $\mathrm{I} .7 \pm 0.4$ \\
\hline $50 \mu \mathrm{g} / \mathrm{ml}$ & $2.1 \pm 0.4$ & $1.1 \pm 0.4$ & $0.9 \pm 0.3$ \\
\hline $100 \mu \mathrm{g} / \mathrm{ml}$ & $1.5 \pm 0.5$ & $1.2 \pm 0.2$ & $2.1 \pm 0.9$ \\
\hline $200 \mu \mathrm{g} / \mathrm{ml}$ & $6.3 \pm 2.8$ & $1.8 \pm 0.5$ & $2.8 \pm 0.7$ \\
\hline $500 \mu \mathrm{g} / \mathrm{ml}$ & $17.5 \pm 1.4 * * *$ & $1.9 \pm 0.5$ & $1.0 \pm 0.3$ \\
\hline
\end{tabular}

Direct effects were measured immediately after addition of particles, effects after surface area cycling were measured following 8 hour rotation at $0.43 \mathrm{~Hz}$ with or without particles. Adsorption surface tension $\left(\gamma_{\text {ads }}\right)$ was obtained from the value of a static bubble. Surface tension at minimal bubble size $\left(\gamma_{\min }\right)$ was recorded during pulsation. Values are given as means \pm SEM of at least 4 experiments. $*$ indicates $p$ values $<0.05$; $* *$ indicates $\mathrm{P}$ values $<0.0 \mathrm{I}$; $* * *$ indicates $\mathrm{p}$ values $<0.00 \mathrm{I}$; all compared with the control without particles $(0 \mu \mathrm{g} / \mathrm{ml})$. In case of surface area cycling, the $0 \mu \mathrm{g} / \mathrm{ml}$ control was rotated for 8 hours at $0.43 \mathrm{~Hz}$. NSP - nanosized particles; MSP - microsized particles.

$\mathrm{TiO}_{2}$ aggregates were found after rotation (Figure 3F). These aggregates were larger in size than the $\mathrm{TiO}_{2}$ aggregates in the non-rotated sample (Figure 3D).

\section{Effect of inhaled particles on surfactant ultrastructure in rats}

Semiquantitative analysis of intra-alveolar active (tubular myelin and lamellar bodies) and inactive surfactant subtypes (unilamellar vesicles) did not differ between both groups. There were no signs of alveolar oedema or inflammation.

\section{Discussion}

The present data show that nanosized particles, but not microsized particles, induce a dysfunction of pulmonary surfactant. Nanosized titanium dioxide as well as nano- sized polystyrene particles at high concentrations can induce a slight pulmonary surfactant dysfunction in vitro. Interestingly, surface area cycling in vitro aggravated the surfactant dysfunction induced by nanoparticles, both by $\mathrm{TiO}_{2}$ NSP and by polystyrene NSP. In addition, biophysical alterations of pulmonary surfactant by $\mathrm{TiO}_{2} \mathrm{NSP}$ were accompanied by changes of the surfactant ultrastructure indicating increased surfactant subtype conversion.

A direct interaction between particles and the surfactant constituents is the most likely explanation for the observed surfactant dysfunction. It is well known that phospholipids bind to particles $[10,14,23]$ and to $\mathrm{TiO}_{2}$ structures [24,25]. In this respect, surface area seems to be the major determinant of the observed biophysical and ultrastructural changes. Accordingly, particles with the 

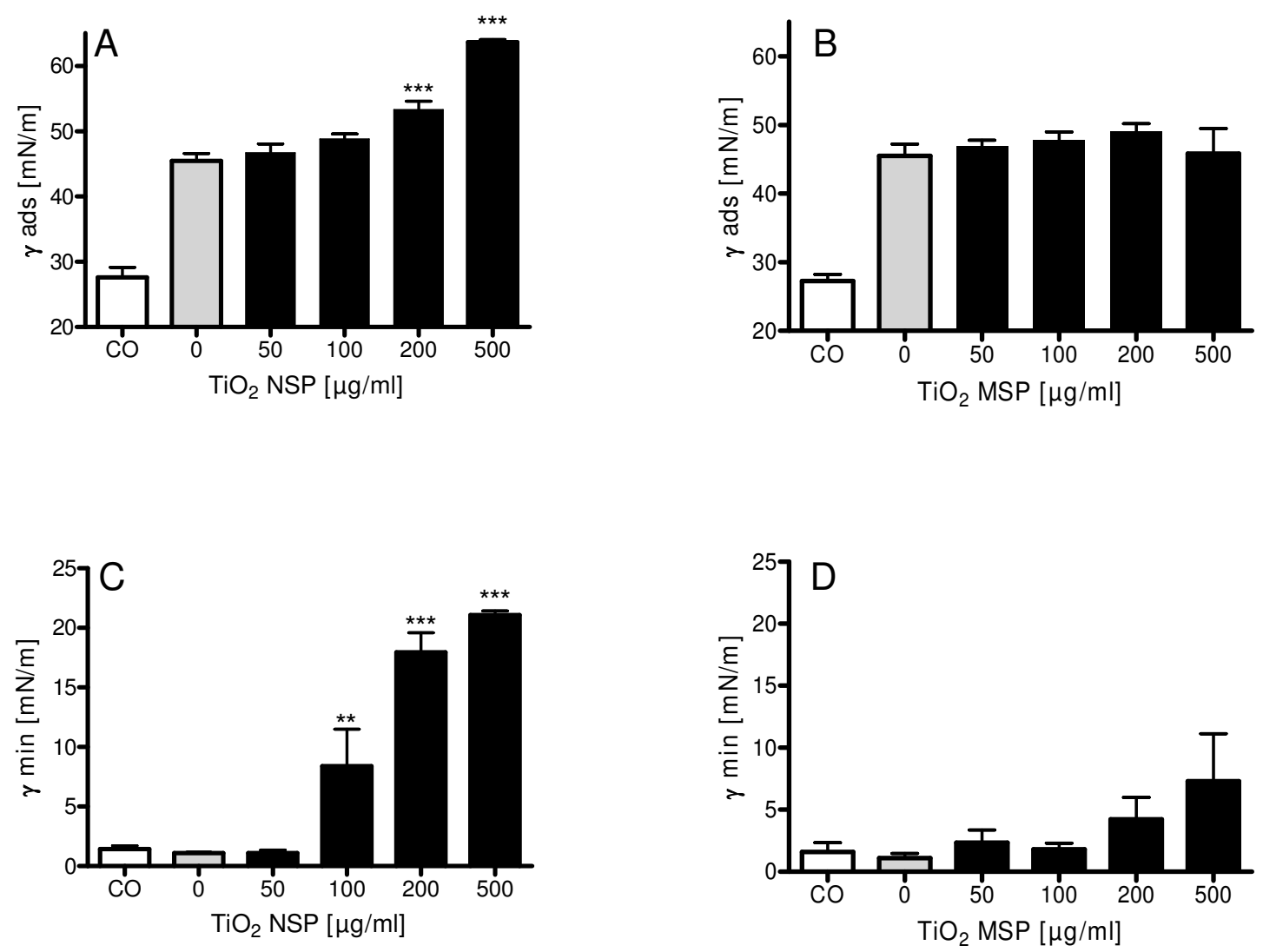

Figure 2

Surface activity evaluated with the pulsating bubble surfactometer following 8 hour rotation at $0.43 \mathrm{~Hz}$. A) Influence of $\mathrm{TiO}_{2}$ NSP on adsorption surface tension $\left(\gamma_{\text {ads }}\right)$ at a static bubble condition. B) Influence of $\mathrm{TiO}_{2} \mathrm{MSP}_{\text {on }} \gamma_{\mathrm{ads}} \mathrm{C}$ ) Influence of $\mathrm{TiO}_{2}$ NSP on surface tension at minimal bubble size $\left(\gamma_{\mathrm{min}}\right)$ during pulsation D) $\mathrm{TiO}_{2}$ MSP effect on $\gamma_{\mathrm{min}}$. Values are given as means \pm SEM of at least 4 experiments. $* *$ indicates $p$ values $<0.0$ I; $* * *$ indicates $p$ values $<0.00$ I; both compared with the rotated $0 \mu \mathrm{g} / \mathrm{ml}$ particle concentration (grey columns). CO/white columns - control surfactant which was placed for 8 hours in an incubator without rotation.

highest surface area - $\mathrm{TiO}_{2} \mathrm{NSP}$ and also reference polystyrene NSP - induced the most prominent alterations. Microsized particles with a relatively low surface area did not induce a surfactant dysfunction in our study.

In separate experiments, we compared equal surface areas by testing very high microparticle mass concentrations. With concentrations of $\sim 10 \mathrm{mg} / \mathrm{ml} \mathrm{TiO}_{2} \mathrm{MSP}$ and quartz MSP, we observed a strong surfactant dysfunction. However, the experimental conditions were limited because microsized particles at this very high concentration aggregated and rapidly sedimented to the bottom of the test capillary. By this segregation, the phospholipid concentra- tion was not stable which limits the comparison of NSP and MSP at similar surface areas.

Bakshi and coworkers demonstrated a potent pulmonary surfactant dysfunction at low concentrations of $\sim 2 \mu \mathrm{g} / \mathrm{ml}$ gold nanoparticles [14]. In contrast, much higher concentrations of $\mathrm{TiO}_{2} \mathrm{NSP}$ were required to induce an increase of surface tension in our experiments. In addition, the degree of surfactant dysfunction was less with $\mathrm{TiO}_{2} \mathrm{NSP}$ in our study compared to the gold nanoparticles used by Bakshi et al. Differences in 1) the measuring system, 2) the surfactant preparation and concentration, or 3 ) the nanoparticles themselves might account for the discrepancy. 

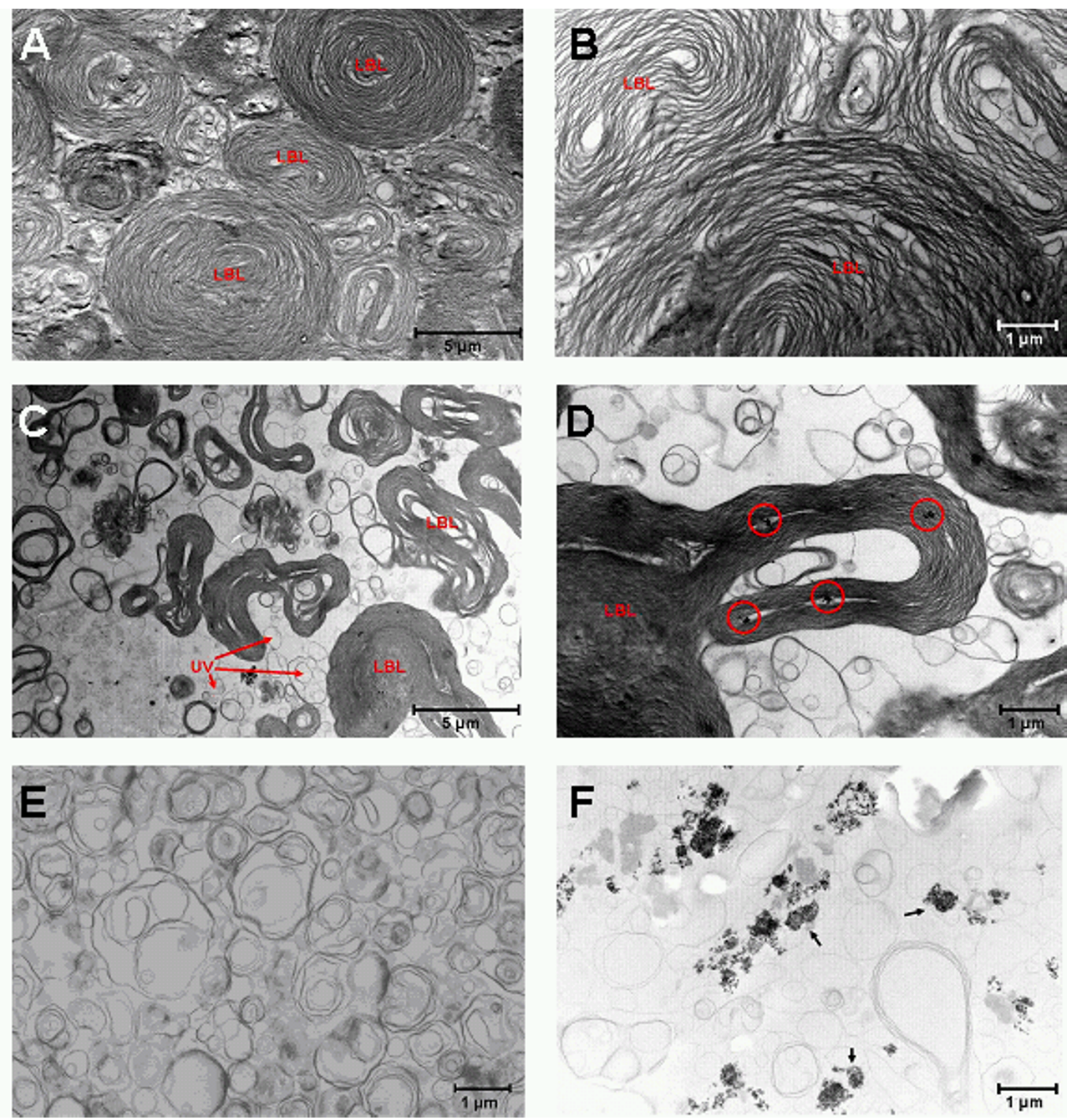

Figure 3

Representative transmission electron microscope pictures of the surfactant ultrastructure. A) and B) untreated control surfactant. C) and D) porcine surfactant after addition of $100 \mu \mathrm{g} / \mathrm{ml} \mathrm{TiO}_{2}$ nanosized particles. Red circles show small particle aggregates. E) Control surfactant after 8 hours rotation at $0.43 \mathrm{~Hz}$ and $37^{\circ} \mathrm{C}$. F) Surfactant after 8 hours rotation at $0.43 \mathrm{~Hz}$ and $37^{\circ} \mathrm{C}$ in the presence of $100 \mu \mathrm{g} / \mathrm{ml} \mathrm{TiO}_{2}$ nanosized particles. Black arrows show large particle aggregates; Ibl lamellar body like forms; ulv - unilamellar vesicles. 
Both, the pulsating bubble surfactometer (PBS) and the captive bubble surfactometer (CPS) are able to evaluate low surface tensions [26] while the CPS is regarded to yield even lower surface tensions [27] which makes differences in the device an unlikely explanation. Regarding surfactant preparation and concentration, we used Curosurf $^{\otimes}$, a natural surfactant derived from minced porcine lungs [28] while a semisynthetic surfactant composed of two phospholipids plus SP-B was used by Bakshi. It is unlikely that differences in the surfactants are solely responsible for the different effects seen with gold nanoparticles and $\mathrm{TiO}_{2}$ NSP. Both surfactants have been demonstrated to have excellent surface activity and to achieve very low surface tensions under compression at the concentrations used. The most likely explanation for the potent dysfunction in the study by Bakshi seems related to the material properties (size/surface) of the gold nanoparticles. Since the gold NSP had citrate groups on their surface, aggregation is mostly avoided [29]. In contrast, pure $\mathrm{TiO}_{2}$ nanoparticles highly aggregate. Although the surface area is not known for the gold NSP from Bakshis study, it is likely that the surface area per mass unit is higher for the citrate coated gold NSP than for the $\mathrm{TiO}_{2}$ NSP. This could explain the more potent induction of surfactant dysfunction by gold NSP compared to $\mathrm{TiO}_{2}$ NSP because surfactant components could be bound to the large gold nanoparticle surface area making them unavailable for lowering surface tension at the air-liquid interface.

In an attempt of direct comparison between $\mathrm{TiO}_{2} \mathrm{NSP}$ and the gold nanoparticles by Bakshi ( $15 \mathrm{~nm})$, we tested commercially available gold NSP with citrate coating (5 $\mathrm{nm}$ ) in single experiments. Interestingly, at equal mass the surfactant dysfunction by gold NSP was stronger compared with $\mathrm{TiO}_{2}$ NSP. However, the dysfunction was less compared with data from Bakshi et al., but this discrepancy can be accounted to differences in surface area of the gold NSP or the surfactant preparations used in both studies.

The in vivo conversion of surface active LA to inferior SA can be simulated in vitro by surface area cycling [16]. By this technique, the impact of meconium, serum proteins, or surfactant proteins during the surfactant conversion process have been studied [19,30-32]. We assessed the effect of $\mathrm{TiO}_{2} \mathrm{NSP}$ on the conversion process. Importantly, a dose-dependent increase in surface tension was obtained. Remarkably, this effect was much stronger than the direct biophysical effect of $\mathrm{TiO}_{2} \mathrm{NSP}$ without cycling. TEM pictures demonstrated that the occurrence of unilamellar vesicles was independent from NSP presence. Possibly, binding of NSP to SP-B and subsequent loss of SP-B from the air-liquid-interface could explain the loss of surface activity following surface area cycling in the presence of NSP. In vivo, SP-B becomes cleaved by a serine active carboxylesterase called convertase [33-35]. However, Curosurf $^{\circledast}$ is prepared by chlorofom extraction and hence does not contain convertase [20]. Therefore, intact SP-B should be present in Curosurf ${ }^{\oplus}$ following surface area cycling. We speculate that free SP-B could interact with $\mathrm{TiO}_{2}$ NSP which in turn becomes depleted leading to disturbed surfactant function. High ability of SP-B to bind to surfaces during surface area cycling was shown before when binding of SP-B to tube walls was investigated during surface area cycling [18]. Unfortunately, we were not able to provide direct evidence of binding of SP-B to $\mathrm{TiO}_{2}$ NSP by TEM due to methodological limitations.

Admittedly, inhaled particles act directly on the surfactant layer at the air-liquid interface and not primarily through the subphase as in our in vitro experiments. However, after deposition at the air-liquid interface the particles subsequently become dissolved in the epithelial lining layer and interfere with the dynamic process of phospholipid arrangement at the interface. Therefore, the assay system with the pulsating bubble surfactometer is at least capable to demonstrate differential effects of nanoparticles versus microparticles in phospholipid suspensions when particles interfere with the formation of the surfactant layer from the hypophase. It is very well conceivable that the initial effect of particles might even be greater when they are reaching the interface directly.

Although we have demonstrated that $\mathrm{TiO}_{2}$ NSP elicited biophysical and structural changes of surfactant in vitro, the in vivo relevance has to be scrutinized because the particle concentrations that we found effective in vitro can hardly occur in vivo. With the human alveolar surface area of $\sim 100 \mathrm{~m}^{2}$ and assuming an average thickness of the alveolar lining fluid of approximately $200 \mathrm{~nm} \mathrm{[36],} \mathrm{the}$ amount of alveolar lining fluid can be assessed as 20 ml. In accordance, the epithelial lining fluid has been suggested to be $6 \mathrm{ml} / \mathrm{L}$ total lung capacity, resulting in $40 \mathrm{ml}$ in man [37]. With the assumption of a particle concentration of $100 \mu \mathrm{g} / \mathrm{m}^{3}$, which can occur in polluted inner cities, and an alveolar deposition rate as high as 50\%, the amount of particles deposited per day would be $\sim 360 \mu \mathrm{g}$. At steady state, this would result in a concentration of $\sim 10$ $\mu \mathrm{g}$ nanoparticles per $\mathrm{ml}$ alveolar lining fluid. This particle concentration is far below what has been demonstrated to cause a surfactant dysfunction in our study. In addition, clearance of particles and secretion of newly synthesized surfactant would further improve this particle/surfactant ratio and consequently question whether nanoparticles can cause a surfactant alteration under these conditions in vivo. This view is supported by our experimental evidence in rats. Following inhalation of $\mathrm{TiO}_{2}$ particles that were aerosolized and adjusted to result in the highest technically possible alveolar deposition of $60 \mu \mathrm{g}$ particles per animal, surfactant ultrastructure was found unaffected in 
vivo. Assuming an alveolar lining fluid in rats of approximately $70 \mu \mathrm{L}$ [36], the in vivo particle concentration in the epithelial lining fluid would have been approximately $53.5 \mu \mathrm{g} / \mathrm{mL}$ (normalized to $1.5 \mathrm{mg} / \mathrm{ml}$ phospholipids and assuming static conditions). Noteworthy, the local concentration at the air-liquid interface was probably much higher suggesting that no changes of surfactant ultrastructure occur in vivo under acute maximal $\mathrm{TiO}_{2}$ particle exposure.

Although these considerations suggest that the impact of $\mathrm{TiO}_{2}$ NSP on surfactant function in the human lung is highly unlikely to cause adverse effects in healthy individuals, in diseased subjects, however, additive effects of NSP on pulmonary surfactant function and ultrastructure have to be taken into account. For example, it has been demonstrated that a pulmonary surfactant dysfunction can be found in various airway diseases like asthma [38], cystic fibrosis [39], or after lung transplantation [40]. In particular, leakage of plasma proteins into the airway lumen is known to induce a surfactant dysfunction $[41,42]$. Importantly, NSP can induce [43-45] or enhance [46,47] pulmonary inflammation which is accompanied by protein leakage. This in turn could lead to a surfactant dysfunction in vivo. Moreover, NSP are able to induce oxidative stress and lipid peroxidation [48-50]. Oxidative stress with lipid peroxidation can induce an increase in surface tension $[51,52]$. In addition, NSPs emitted by engines are contaminated with alkanes and sulfates [53] and it is known, that eicosane, a specific n-alkane constituent of diesel exhaust NSPs, can affect the biophysical surfactant function [54]. Therefore, nanoparticles might amplify alterations of the pulmonary surfactant system, particularly under predisposed conditions of airway inflammation.

\section{Conclusion}

Taken together, $\mathrm{TiO}_{2}$ NSP induce biophysical and structural alterations of pulmonary surfactant in vitro. Under dynamic conditions of surface area cycling, this interfering impact is aggravated. Although our data do not suggest that inhalation of nanoparticles cause a significant disturbance of the pulmonary surfactant system in vivo, nanoparticles might be detrimental in patients with preexisting airway disease.

\section{Abbreviations}

CPS: Captive bubble surfactometer; CO: Control; DPPC: Dipalmitoylphosphatidylcholine; LA: Large aggregates; lbl: Lamellar body-like forms; MSP: Microsized particles; NSP: Nanosized particles; PBS: Pulsating bubble surfactometer; PM: Particulate matter; SA: Small aggregates; SEM: Standard error of the mean; SP: Surfactant protein; TEM: Transmission electron microscope; $\mathrm{TiO}_{2}$ : Titanium dioxide; ulv: Unilamellar vesicles; $\gamma_{\min }$ : surface tension at minimum bubble size; $\gamma_{\text {ads }}$ : adsorption surface tension

\section{Competing interests}

The authors declare that they have no competing interests.

\section{Authors' contributions}

CS planned the concept and study design, performed the surface area cycling as well as pulsating bubble surfactometer experiments, interpreted the results and wrote major parts of the manuscript. CM performed the electron microscopic analyses of the surfactant ultrastructure and interpreted the results. KP performed the electron microscopic analyses of the particles and interpreted the results. AS performed the electron microscopic analyses of the surfactant ultrastructure and interpreted the results. $\mathrm{MN}$ participated in characterization of the particles and interpreted the results. HDL made substantial contributions to the analysis and interpretation of the data. $\mathrm{AB}$ made substantial contributions to the analysis and interpretation of the data. NK made substantial contributions to the analysis and interpretation of the data. VJE participated in planning the study design and made substantial contributions to the analysis and interpretation of the data. JMH planned the concept and study design, made substantial contributions to the analysis and interpretation of the data and wrote major parts of the manuscript. All of the authors have critically read the manuscript and approved its submission.

\section{Additional material}

\section{Additional file 1}

Characterization of the particles. Representative transmission electron microscopic pictures of the particles [see figure S1 in additional file 1] as well as a table with the characteristics of the particles [see table S1 in additional file 1] are shown.

Click here for file

[http://www.biomedcentral.com/content/supplementary/14659921-10-90-S1.DOC]

\section{Acknowledgements}

The authors thank Dr. Wolfgang G. Kreyling and Dr. Ruud Veldhuizen for helpful discussion and Prof. Dr. Hartmut Hecker for statistical advice.

\section{References}

I. Ellsworth DK, Verhulst D, Spitler TM, Sabacky BJ: Titanium nanoparticles move to the marketplace. Chemical Innovation 2000, 30:30-35.

2. Dockery DW, Pope CA III, Xu X, Spengler JD, Ware JH, Fay ME, et al.: An association between air pollution and mortality in six U.S. cities. N Engl J Med 1993, 329:1753-I759.

3. Wichmann HE, Spix C, Tuch T, Wolke G, Peters A, Heinrich J, et al.: Daily mortality and fine and ultrafine particles in Erfurt, Germany part I: role of particle number and particle mass. Res Rep Health Eff Inst 2000:5-86.

4. Li N, Hao M, Phalen RF, Hinds WC, Nel AE: Particulate air pollutants and asthma. A paradigm for the role of oxidative stress in PM-induced adverse health effects. Clin Immunol 2003, 109:250-265. 
5. Kirkham P, Rahman I: Oxidative stress in asthma and COPD: antioxidants as a therapeutic strategy. Pharmacol Ther 2006, I I I:476-494.

6. Collaco JM, Vanscoy L, Bremer L, McDougal K, Blackman SM, Bowers $\mathrm{A}$, et al.: Interactions between secondhand smoke and genes that affect cystic fibrosis lung disease. JAMA 2008, 299:417-424

7. Goss CH, Newsom SA, Schildcrout JS, Sheppard L, Kaufman JD: Effect of ambient air pollution on pulmonary exacerbations and lung function in cystic fibrosis. Am J Respir Crit Care Med 2004, 169:816-821.

8. Oberdorster G, Oberdorster E, Oberdorster J: Nanotoxicology: an emerging discipline evolving from studies of ultrafine particles. Environ Health Perspect 2005, I I 3:823-839.

9. Ikegami M: Surfactant catabolism. Respirology 2006, I I (Suppl):S24-S27.

10. Mornet S, Lambert O, Duguet E, Brisson A: The formation of supported lipid bilayers on silica nanoparticles revealed by cryoelectron microscopy. Nano Lett 2005, 5:28I-285.

II. Kendall M: Fine airborne urban particles (PM2.5) sequester lung surfactant and amino acids from human lung lavage. $\mathrm{Am}$ J Physiol Lung Cell Mol Physiol 2007, 293:LI 053-LI 058.

12. Hill CA, Wallace WE, Keane MJ, Mike PS: The enzymatic removal of a surfactant coating from quartz and kaolin by P388D I cells. Cell Biol Toxicol 1995, I I:1 19-128.

13. Schleh C, Hohlfeld JM: Interaction of nanoparticles with the pulmonary surfactant system. Inhal Toxicol 2009, 21:97-103.

14. Bakshi MS, Zhao L, Smith R, Possmayer F, Petersen NO: Metal nanoparticle pollutants interfere with pulmonary surfactant function in vitro. Biophys / 2008, 94:855-868.

15. Ku T, Gill S, Lobenberg R, Azarmi S, Roa W, Prenner EJ: Size dependent interactions of nanoparticles with lung surfactant model systems and the significant impact on surface potential. J Nanosci Nanotechnol 2008, 8:297I-2978.

16. Gross NJ, Narine KR: Surfactant subtypes of mice: metabolic relationships and conversion in vitro. J Appl Physiol 1989, 67:4I4-42I.

17. Beatty AL, Malloy JL, Wright JR: Pseudomonas aeruginosa degrades pulmonary surfactant and increases conversion in vitro. Am J Respir Cell Mol Biol 2005, 32: I28-134

18. Inchley K, Cockshutt A, Veldhuizen R, Possmayer F: Dissociation of surfactant protein $B$ from canine surfactant large aggregates during formation of small surfactant aggregates by in vitro surface area cycling. Biochim Biophys Acta 1999, I 440:49-58.

19. Kakinuma R, Shimizu H, Ogawa Y: Effect of meconium on the rate of in vitro subtype conversion of swine pulmonary surfactant. Eur J Pediatr 2002, 161:31-36.

20. Veldhuizen RA, Yao LJ, Lewis JF: An examination of the different variables affecting surfactant aggregate conversion in vitro. Exp Lung Res 1999, 25:|27-|4|.

21. Price OT, Asgharian B, Miller FJ, Cassee FR, de Winter-Sorkina R: Multiple Path Particle Dosimetry model (MPPD vI.0): A model for human and rat airway particle dosimetry. RIVM rapport 650010030 CD-rom publication 2002

22. Schmiedl A, Hoymann HG, Ochs M, Menke A, Fehrenbach A, Krug N, et al.: Increase of inactive intra-alveolar surfactant subtypes in lungs of asthmatic Brown Norway rats. Virchows Arch 2003 , 442:56-65

23. Blank F, Rothen-Rutishauser BM, Schurch S, Gehr P: An optimized in vitro model of the respiratory tract wall to study particle cell interactions. J Aerosol Med 2006, 19:392-405.

24. Fortunelli A, Monti S: Simulations of lipid adsorption on $\mathrm{TiO} 2$ surfaces in solution. Langmuir 2008, 24:10145-10154.

25. Jiang C, Gamarnik A, Tripp CP: Identification of lipid aggregate structures on TiO2 surface using headgroup IR bands. J Phys Chem B 2005, 109:4539-4544.

26. Putz G, Goerke J, Taeusch HW, Clements JA: Comparison of captive and pulsating bubble surfactometers with use of lung surfactants. J Appl Physiol I994, 76: | 425-I43I.

27. Rudiger M, Kolleck I, Putz G, Wauer RR, Stevens P, Rustow B: Plasmalogens effectively reduce the surface tension of surfactant-like phospholipid mixtures. Am J Physiol 1998, 274:LI43-LI48.

28. Bernhard W, Mottaghian J, Gebert A, Rau GA, Hardt von der, Poets CF: Commercial versus native surfactants. Surface activity, molecular components, and the effect of calcium. Am J Respir Crit Care Med 2000, 162:1524-1533.
29. Kim T, Lee $\mathrm{CH}$, Joo SW, Lee K: Kinetics of gold nanoparticle aggregation: experiments and modeling. J Colloid Interface $\mathrm{Sci}$ 2008, 3 I 8:238-243.

30. Veldhuizen RA, Inchley K, Hearn SA, Lewis JF, Possmayer F: Degradation of surfactant-associated protein B (SP-B) during in vitro conversion of large to small surfactant aggregates. Biochem J 1993, 295(Pt I): |4|-|47.

31. Ueda T, lkegami M, Jobe A: Surfactant subtypes. In vitro conversion, in vivo function, and effects of serum proteins. $\mathrm{Am}$ Respir Crit Care Med 1994, 149: I 254-1259.

32. Veldhuizen RA, Yao LJ, Hearn SA, Possmayer F, Lewis JF: Surfactant-associated protein $A$ is important for maintaining surfactant large-aggregate forms during surface-area cycling. Biochem J 1996, 3 I3(Pt 3):835-840.

33. Gross NJ, Schultz RM: Requirements for extracellular metabolism of pulmonary surfactant: tentative identification of serine protease. Am J Physiol 1992, 262:L446-L453.

34. Gross NJ, Bublys V, D'Anza J, Brown CL: The role of alpha I-antitrypsin in the control of extracellular surfactant metabolism. Am J Physiol 1995, 268:L438-L445.

35. Ruppert C, Pucker C, Markart P, Schmidt R, Grimminger F, Seeger W, et al: Selective inhibition of large-to-small surfactant aggregate conversion by serine protease inhibitors of the bis-benzamidine type. Am J Respir Cell Mol Biol 2003, 28:95-I02.

36. Bastacky J, Lee CY, Goerke J, Koushafar H, Yager D, Kenaga L, et al: Alveolar lining layer is thin and continuous: low-temperature scanning electron microscopy of rat lung. J Appl Physiol 1995, 79:1615-1628.

37. Effros RM, Feng NH, Mason G, Sietsema K, Silverman P, Hukkanen J: Solute concentrations of the pulmonary epithelial lining fluid of anesthetized rats. J Appl Physiol 1990, 68:275-28I.

38. Hohlfeld JM, Ahlf K, Enhorning G, Balke K, Erpenbeck VJ, Petschallies J, et al.: Dysfunction of pulmonary surfactant in asthmatics after segmental allergen challenge. Am J Respir Crit Care Med 1999, 159:1803-1809.

39. Griese $M$, Birrer $P$, Demirsoy A: Pulmonary surfactant in cystic fibrosis. Eur Respir J 1997, 10:1983-1988.

40. Hohlfeld JM, Tiryaki E, Hamm H, Hoymann HG, Krug N, Haverich A, et al:: Pulmonary surfactant activity is impaired in lung transplant recipients. Am J Respir Crit Care Med 1998, I58:706-7I2.

41. Ikegami M, Jobe A, Jacobs $H$, Lam R: A protein from airways of premature lambs that inhibits surfactant function. J Appl Physiol 1984, 57: I |34-I| 42

42. Holm BA, Notter RH, Finkelstein JN: Surface property changes from interactions of albumin with natural lung surfactant and extracted lung lipids. Chem Phys Lipids 1985, 38:287-298.

43. Sung JH, Ji JH, Yoon JU, Kim DS, Song MY, Jeong J, et al.: Lung function changes in Sprague-Dawley rats after prolonged inhalation exposure to silver nanoparticles. Inhal Toxicol 2008, 20:567-574.

44. Niwa Y, Hiura Y, Sawamura H, Iwai N: Inhalation exposure to carbon black induces inflammatory response in rats. Circ J 2008, 72:144-149.

45. Ferin J, Oberdorster G, Penney DP: Pulmonary retention of ultrafine and fine particles in rats. Am J Respir Cell Mol Biol 1992, 6:535-542.

46. Inoue K, Takano H, Yanagisawa R, Hirano S, Sakurai M, Shimada A, et al.: Effects of airway exposure to nanoparticles on lung inflammation induced by bacterial endotoxin in mice. Environ Health Perspect 2006, I I 4: 1325-1330.

47. Inoue K, Takano H, Yanagisawa R, Ichinose T, Sakurai M, Yoshikawa $\mathrm{T}$ : Effects of nano particles on cytokine expression in murine lung in the absence or presence of allergen. Arch Toxicol 2006, 80:614-619.

48. Worle-Knirsch JM, Kern K, Schleh C, Adelhelm C, Feldmann C, Krug HF: Nanoparticulate vanadium oxide potentiated vanadium toxicity in human lung cells. Environ Sci Technol 2007, 4I:33I-336.

49. Arora S, Jain J, Rajwade JM, Paknikar KM: Cellular responses induced by silver nanoparticles: In vitro studies. Toxicol Lett 2008, 179:93-100.

50. Sayes CM, Marchione AA, Reed KL, Warheit DB: Comparative pulmonary toxicity assessments of $\mathrm{C} 60$ water suspensions in rats: few differences in fullerene toxicity in vivo in contrast to in vitro profiles. Nano Lett 2007, 7:2399-2406.

5I. Seeger W, Lepper $\mathrm{H}$, Wolf HR, Neuhof $\mathrm{H}$ : Alteration of alveolar surfactant function after exposure to oxidative stress and to 
oxygenated and native arachidonic acid in vitro. Biochim Biophys Acta 1985, 835:58-67.

52. Shelley SA: Oxidant-induced alterations of lung surfactant system. J Fla Med Assoc 1994, 8 I:49-5I.

53. Kittelson DB: Engines and nanoparticles: A review. Journal of Aerosol Science 1998, 29:575-588.

54. Kanno S, Furuyama A, Hirano S: Effects of eicosane, a component of nanoparticles in diesel exhaust, on surface activity of pulmonary surfactant monolayers. Arch Toxicol 2008, 82:84I-850.

Publish with Bio Med Central and every scientist can read your work free of charge

"BioMed Central will be the most significant development for disseminating the results of biomedical research in our lifetime. "

Sir Paul Nurse, Cancer Research UK

Your research papers will be:

- available free of charge to the entire biomedical community

- peer reviewed and published immediately upon acceptance

- cited in PubMed and archived on PubMed Central

- yours - you keep the copyright

Submit your manuscript here:

http://www.biomedcentral.com/info/publishing_adv.asp
BioMedcentral 